\title{
ERDŐS Ákos \\ A Vám- és Pénzügyőrség kábítószer-ellenes tevékenysége a rendszerváltást követő első évtizedben
}

$\mathrm{A}$ homo sapiens mindig is arra törekedett, hogy létfeltételeit, fennmaradását biztosítsa. A későbbiekben, az egyre összetettebb közösségi struktúrák létrehozását is ez motiválta. Ennek hozadékaként születtek meg az államok, az emberi együttműködés magas fokán elhelyezkedő, szervezett társadalmi rendszerek. ${ }^{1}$

Az államok szembe kerültek a kábítószerfogyasztás által teremtett helyzettel, hiszen a kábítószert fogyasztók — azon túl, hogy saját egészségüket is rombolták — olyan helyzetet idéztek elö, amellyel a fennálló társadalmi berendezkedést valamilyen formában gyengítették. Ebből fakadóan az állam kábítószer elleni fellépése csaknem egyidős a kábítószer használattal. A kábítószer használatának számos oka lehet ugyan, azonban többnyire valamilyen pótcselekvés, mivel a kábítószer fogyasztó nem képes a gondjai megoldására, illetve vágyai elérésére, ezért folyamodik a kábítószerhez. „Az úgynevezett pszichoaktív anyagok alkalmazásának funkciója az örömszerzés, bódulatkeltés, a vágyott, de el nem ért boldogság, harmónia megtalálása fogyasztásuk révén."2

A gyengeakaratú, befolyásolható egyéniségek könnyen rákaphatnak a kábító anyagok fogyasztására, annak rabjává válhatnak, többé már nem lesznek urai akaratuknak „,Amikor egy államban a közös eredetü problémával küzdö egyének száma, illetve a probléma minösége olyan méreteket ölt, hogy az a társadalom egészséges müködését fenyegeti, az állam cselekvési tervek kidolgozásával, új normák bevezetésével, vagy a már meglévö szabályzók módositásával igyekszik megoldást találni s megóvni a fennálló társadalmi struktúrát. Alapvetōen ez indokolja a drogok felhasználásának, eloállitásának, vagy éppen forgalmazásának jogszabályi keretek közé szoritását. "’3 A kábítószer függőségből való kikerüléshez már rögös utat kell bejárni, amelyhez általában a társadalom, illetve az állam segítsége is szükséges. Mindez a társadalom és az állam viszonylag erőteljes forrásait köti le. Ebben a küzdelemben volt és van nem kis szerepe a Vám- és Pénzügyőrségnek is.

A XIX-XX. századtól egyre inkább szabályozott a kábítószerek ellenőrzése. A kábítószerekkel való visszaélések tekintetében a legmeghatározóbb rendvédelmi testületek a Magyar Királyi Csendőrség (18811945) és a rendőrség(ek), valamint a vámhivatalok, majd a Vám- és Pénzügyőrség voltak, természetesen mindegyik testület a saját feladat és hatáskörén belül tevékenykedett. „In eodem prato bos herbam quaerit, canis leporem, ciconia lacertam" (Ugyanazon a réten a marha füvet keres, a kutya nyulat, a gólya gyíkot.)

$\mathrm{Az}$ érintett magyar rendvédelmi testületek szolgálati tevékenységében egyre meghatározóbb szerepet töltött be az illegális pszichoaktív szerek terjesztése és használata elleni küzdelem. ${ }^{4}$

A rendőrséget és a vámhatóságot, eltérő múltja, feladatai ellenére az e területen jelentkező kihívások szorosan összekapcsolták. Más-más megközelítésből és módszerrel ugyan, de együtt igyekeztek megküzdeni az új feladataikkal.

Az idő múlásával folyamatosan változó szerhasználói szubkultúra, és az azt követni igyekező jogszabályi környezet alakulásához a rendvédelmi testületek is alkalmazkodtak a szolgálati feladataik végrehajtása során. E változások egyik legjelentősebb időszaka az 1990-es évekre tehető. A társadalmi és politikai rendszer átalakulásából fakadóan a magyar drogtérben is érzékelhető változások következtek be. Az illegális pszichoaktív szerek csempészetének, terjesztésének és fogyasztásának mennyiségi, valamint minőségi növekedése következtében, a rendvédelmi testületek közül a Vám- és Pénzügyörség életében keletkeztek talán a legjelentősebb változások.

\section{Kábítószer helyzet változásai Magyarországon a rendszerváltás időszakában}

Magyarországon a pszichoaktív szerek (alkohol, kábítószerek, gyógyszerek) használata - hasonlóan más nemzetekhez - egyáltalán nem új keletü jelenség, a szocializmus idején sem volt az. Hazánk a II. világháborút követően a keleti blokk befolyása alá került.

A magyar pártállam paternalista állami gondoskodással — a hallgatás politikai követelményével igyekezett orvosolni a szerhasználattal kapcsolatos problémákat: „, . . . a nyilvános diskurzusban tabusította - 1985-ig újságcikk nem jelenhetett meg a témáról..." 5

A valóság ugyanakkor az volt, hogy bár a pszichoaktív szerhasználat — minőségben, mennyiségben és a fogyasztási mintázatban — sokban eltért a rendszerváltást követő időszaktól, e problémától a szocialista állami rendszer sem volt mentes.

A korabeli kábítószerfogyasztási helyzetről — a téma tiltásának enyhülésével — kiadványok is megjelentek ,,Tévesek azok a 6-8 évvel ezelötti vélemények, hogy a drogabúzus megszünöben van. A gyakorlat azt mutatja, hogy minden évben növekszik az ügyek száma. Mintegy 2-3 éve a klasszikus kábitószerek fogyasztása 
is érezhetően emelkedett, ezek az érintett fogyasztók - elsösorban fiatalok - részéröl hozzáférhetök (heroin, LSD, stb.)."6

Az 1989-ben elkezdődő politikai átalakulással, a köztársaság kikiáltásával, a vasfüggöny leomlásával egy olyan korszak vette kezdetét, ahol megszüntek az olyan rendszerspecifikus jellemzők, mint az ország viszonylagos zártsága, a szigorú határellenőrzés vagy a szabad mozgás korlátozása. Mindezek pedig kedvezően hatottak a kábítószer-csempészet, és illegális drogkereskedelem alakulására.

Az 1970-es években a magyar rendőrség még csak a morfin, a hasis és a marihuána élvezetének korlátozott jelenségére hívta fel a politikai vezetők figyelmét. ${ }^{7}$

A kábítószerek jellemzően csempészet, lopás, orvosi vények meghamisítása vagy illegális termesztés által kerültek a fogyasztókhoz. A csempészeti tevékenység jelentős része azonban jellemzően tranzit jelleggel zajlott. 1970 és 1975 között 75 ismertté vált büncselekményt regisztráltak a hatóságok. ${ }^{8} \mathrm{Az}$ 1990-es évekre azonban hazánk is célországgá vált, s az áthaladó kábítószer egyre nagyobb mennyiségben talált itthon gazdára.

Magyarország kábítószer-fogyasztási mintázataival, illetve a fogyasztókkal kapcsolatban tehát már a szocializmus időszakából is rendelkezünk információkkal. Az átfogó adatgyüjtések és kutatások azonban az 1990-1991-re — financiális erőforrások hiányában — elapadtak. „Az elsö olyan felmérésre, amely az összehasonlithatóság metodikai követelményeit is kielégíti, csak 2001-ben került sor.""

Ugyanakkor ad hoc, kisvolumenü kutatások a rendszerváltást követő időszakban is történtek, így a kábítószerekre és fogyasztóikra vonatkozóan a rendszerváltást követő első évtized helyzetéről is vannak ismereteink.

A körzeti orvosok körében végzett országos felmérések adataiból például kiderül, hogy míg 1990-ben 27 000, addig 1992-ben 65000 olyan személyről tudtak az orvosok, akik rendszeres drogfogyasztók voltak. A fogyasztott szerek kapcsán pedig elmondható, hogy a legális szerek (benzodiazepinek, barbiturátok) dominanciája jelentősen csökkent a kábítószerekkel szemben. 1992-től ugrásszerüen emelkedett a heroinfogyasztók száma. ${ }^{10} \mathrm{Az}$ 1990-es években havonta átlagosan 10-15 beteget kezeltek a Péterfy Sándor Utcai Kórház Klinikai Toxikológiai Osztályán. A hazai heroin tartalmú kábítószerfogyasztás tehát az 1990-es években élte virágkorát.

1995-re a Magyarországon használt kábítószerek repertoárja jelentősen kibővült. Az LSD (lizergsavdietilamid) mellett teret hódítottak a különböző amfetaminszármazékok is. ${ }^{11}$ A marihuána fogyasztása pedig már a 90 -es évek elejére tulajdonképpen mindennapossá vált. ${ }^{12}$

A rendszerváltást követő időszakra tehát a kábítószer-bünözés súlyosabb formáitól eltekintve, a kábítószerekkel kapcsolatos probléma minden olyan megnyilvánulása felfedezhető volt hazánkban, amely NyugatEurópában is létezett. ${ }^{13}$

A drogtérben bekövetkező változások kapcsán végezetül említést kell tenni a kábítószerek és fogyasztóinak társadalmi megítélésérool. A pártállami rendszert jellemző hallgatás és tagadás időszakát a probléma (megkésett) felismerése követte, melynek kezelésében jelentős szerepet szánt a jogalkotó a jogszabályi reformoknak.

A kábítószer-fogyasztói magatartás büntetőjogi megítélése körüli jogirodalmi vitát 1986-ban a Legfelsőbb Bíróság azzal zárta le, hogy büntetendőnek mondta ki az ilyen anyagok fogyasztását is. A rendszerváltást követően e kérdés újra előkerült. Egyesek úgy vélték, hogy ez a tiltó megközelítés sérti az egyén önrendelkezési jogát. Az Alkotmánybíróság állásfoglalása szerint ugyanakkor „A méltósághoz való jogot az általános személyiségi jog egyik megfogalmazásának tekintette, amelynek része többek között a személyiség szabad kibontakoztatásához, az önazonossághoz, az önrendelkezési szabadsághoz és az általános cselekvési szabadsághoz való jog. Az emberi méltósághoz való jog — az Alkotmánybiróság gyakorlata szerint - csak az élethez való joggal fennálló egységben korlátozhatatlan. Részjogai, így az önrendelkezési jog, az alkotmány 8. $\S$ (2) bekezdése szerint korlátozható." 14

Ugyanebben a témában a pártpolitika terrénumában jelentős megosztottság alakult ki a konzervatív és liberális nézetek között. E két álláspont küzdelme a 1990-es évek második felétől egészen napjainkig tart. ${ }^{15}$

A kábítószerrel való visszaélés büntetőjogi megítélését tartalmazó tényállás jelentősebb módosításai közül kettőre, ebben az időszakban került sor $(1993,1998)$. A drogpolitikai álláspont föbb vonalait jól mutatják a módosításokat beterjesztő kormány miniszterelnökének akkori szavai: „Tisztában vagyunk azzal, hogy a drog fogyasztása teljes mértében nem szüntethetö meg. De a kérdésre - kábitószer vagy élet - világost választ kell adnunk. És mi azt mondjuk: a kormány az élet oldalán áll. Nem tüzhetünk ki kisebb célt, mint egy drogmentes Magyarország megteremtését. Ezért 1999-ben szigorú kábitószerellenes törvényt léptetünk életbe."16 
A kábítószerpiacon, a fogyasztók körében, valamint a politikai és társadalmi megítélésben bekövetkezett változások együttesen vezettek oda, hogy a rendszerváltást követő első évtizedben, a Vám- és Pénzügyőrség, illetve a Rendőrség jelentős többlet feladatokkal került szembe. Valóságos harc kezdődött az állam és az illegalitásba szorult kábítószer-fogyasztók, valamint az őket kiszolgáló üzérek között. S e küzdelemben a Vám- és Pénzügyőrség szervezetére az idő múlásával egyre nagyobb feladat hárult.

\section{A Vám- és Pénzügyőrség kábítószer-felderítő tevékenysége}

Az illegális kábítószer-kereskedelem elleni küzdelemben a vám- és pénzügyőri szervezet mindig is megkerülhetetlen volt. Ennek oka, hogy az országhatáron átkelő személy- és teherforgalom tüzetes vizsgálata, kezdetektől a pénzügyőri feladatok közé tartozott. Már a Magyar Királyi Pénzügyőrség létrehozásakor is a szervezet „Legfontosabb feladatai közé tartozott, hogy megakadályozza a csempészetet és a pénzügyi törvények és szabályok áthágását." "17

A magyar vámhatóság számára már az 1900-as évek elején sem volt ismeretlen fogalom a pszichoaktív anyagok csempészete. A mohácsi fővámhivatal pénzügyőrei például 1937-ben a egy a Dunán felfelé haladó uszály kormányosának hajófülkéjében, a padló alá rejtve három és fél kilogramm hasist találtak. ${ }^{18}$

A XX. század második felétől azonban a kábítószerek dinamikusan kezdtek betörni az aktuálisan csempészett slágertermékek közé. A kábítószer-szállítások problémája az 1970-es években vált jelentősebbé a Vám- és Pénzügyőrség számára. Ennek ellenére, az ezt megelőző időszakhoz hasonlóan, még nagyon sokáig a kábítószerek csempészetét — pártpolitikai utasításra — a hallgatás homályába tolták a hatóságok.

A nyolcvanas évek végén jelentős változások álltak be. 1988-tól a magyarok a világ összes országába érvényes útlevelet kaptak, ${ }^{19} \mathrm{~s}$ a megnyitott határokat a szó szoros értelmében elárasztották a kábítószercsempészek. Tulajdonképpen hazánkban néhány év alatt lezajlott egy olyan markáns folyamat, amelyhez nyugaton évtizedekre volt szükség. ${ }^{20}$ A Vám- és Pénzügyőrség erre egyáltalán nem volt felkészülve, s a kezdetekben csupán az addig megszerzett szakmai rutin és tapasztalat vezette a vámosok kezét egy-egy felderítés alkalmával.

Kezdetben a felderítések elsősorban a repülőtéren realizálódtak, pedig mindenki számára nyilvánvaló volt, hogy a kábítószerek csempészete a közúti és vasúti forgalomban ugyanúgy folyik.

A nemzetközi forgalmat lebonyolító repülőtér, a kábítószer-felderítés szempontjából elsősorban a kokain tekintetében bírt már akkor is jelentőséggel. Ennek oka az volt, hogy a kokain előállítása Dél-Amerika országaiban összpontosult - 1970-ig Bolívia és Peru volt a legfőbb kokain előállító, ezután azonban Kolumbia vette át az első helyet —, $\mathrm{s}$ annak szállítása a légi forgalomban mutatkozott a legegyszerübbnek. ${ }^{21}$

A repülőgéppel történő szállitás mellett szólt továbbá - a gyorsaság mellett - az útvonalak könnyü variálhatósága, gazdag választéka, amely lehetővé tette, hogy a származási- és célország közötti kapcsolatot eltüntessék, így a szállítmány mentesülhet a „gyanús-profil”-ba sorolás terhe alól. ${ }^{22}$ Harmadrészt pedig az anyag sajátosságából eredően, a magas hatóanyag tartalmú (nagy tisztaságú) kokain szállítása, már kisebb mennyiség esetében is jelentös profittal kecsegtetett. A rendszerváltást követöen egyre gyakrabban és egyre nagyobb mennyiségben került kokain futár a magyar vámosok kezére. (I.sz. melléklet)

A kokain szállítmányok csempészetének módszere alapjaiban véve a ma alkalmazott technikáktól alig tért el. A pénzügyőrök épp úgy ismerték a ruházatban, cipőkben elrejtett csomagokat, mint a folyadékban feloldott, illetve textíliával felitatott kokain csempészetének fogásait. Mindezek mellett szintén nem voltak ismeretlenek az anterográd (a kokainnal töltött kapszulákat lenyelve, a tápcsatornáján keresztül szállítja a kábítószert a csempész. Szakzsargon: „nyelö”) és a retrográd (a kokainnal töltött kapszulákat a végbélbe, illetve a hüvelybe felhelyezve csempészi a kábítószert. Szakzsargon: ,pusher”) szállítók sem a magyar pénzügyőrök elött. Ezt a módszert az angol vámhatóság fedezte fel még 1974-ben, amikor az egyik utas a vámvizsgálat közben meghalt, $\mathrm{s}$ mint a boncoláson kiderült, a testébe rejtett egyik kapszula sérülése, illetve az ebből következő kábítószer túladagolás okozta halálát. Hazánkban az első anterográd csempész elfogására 1995 januárjában került sor Rábafüzesen. A kolumbiai szállító gyomrából összesen 117 darab kapszulát (kb. 940 gr.) találtak elő a pénzügyörök.

A pénzügyőrség tagjainak természetesen nem csupán a kokaincsempészekkel kellett felvenni a versenyt. A kokain - illegális szállításának hosszadalmas, bonyolult jellege okán -, ugyanis a magas árfekvésü anyagok csoportjába tartozik és már az 1990-es években is abba tartozott. 1994-ben 1 gramm kokain közvetlen terjesztői ára megközelítőleg 12000 forint volt hazánkban. E kimagasló ár biztosította, s biztosítja mind a mai napig használatának exkluzív jellegét. Ebböl következően a kábítószer kereslet, számszerüségét tekintve más anyagokra koncentrálódott már ebben az időszakban is. Fővárosi kollégáiktól eltérően, az ország déli és keleti határain szolgálatot teljesítő vámosoknak elsősorban az ópium, az ópiátok, a morfinszármazékok, illetve a marihuána (cannabis) csempészete adott feladatot. 
A kábítószerek közül kiemelt jelentősége volt a heroin csempészetének. Az 1970-es évektöl Európa legfőbb heroin ellátója Törökország volt. Ezt követően 1982-től bekapcsolódtak az illegális kereskedelem vérkeringésébe a pakisztániak, irániak, az indiaiak és a libanoniak is. 1986-tól az ún. „balkáni útvonalra” telepedett szinte a teljes európai heroin kereskedelem. A magyar heroin-piac legfőbb kiszolgálói a koszovói albánokból, illetve arab és nyugat-afrikai állampolgárokból szerveződött csoportok voltak. ${ }^{23}$ A beszállitásban müködtek közre továbbá azok a török származású személyek is, akik az isztambuli elosztókból csempészték a heroint nyugatra. Jól mutatja e csoportok aktivitását és jelentőségét, hogy 1998-ban, a Vám- és Pénzügyörség által a balkáni útvonalon elfogott 328 kábítószercsempész 39\%-a volt albán (64fö; 20\%) vagy török (61 fö; 19\%) állampolgárságú. Az összes többi elkövető (203fö) további 21 nemzet polgáraiból tevődött össze. ${ }^{24}$

A hazánkon átívelö balkáni útvonal, keleti irányból a román, míg délről a szerb (jugoszláv) határszakaszon vezetett be az országba. Az 1990-ben kirobbant délszláv polgárháború következményeként a balkáni útvonal középső ága (Isztambul - Szófia - Nándorfehérvár [Belgrád] - Zágráb - Ljubljana) északabbra húzódott, ezáltal hazánk Európa legjelentősebb tranzit országává vált. 1993-ban a Vám- és Pénzügyőrség által elfogott kábítószer-csempészek 56\%-a a román-, 10\% a szerb határszakaszon, $25 \%$-uk pedig a repülőtéren került feltartóztatásra. ${ }^{25}$

Az 1990-es évek első felében felderített heroin mennyisége dinamikus növekedést mutatott. Az előtalált és lefoglalt kábítószer mennyiségének látványos növekedése is bizonyítja, hogy nem hiába nevezhetjük ezen időszakot a hazai heroin használat virágkorának. Másrészt viszont a bünügyi statisztikai adatok növekvő mutatói azt is jól szemléltetik, hogy a magyar pénzügyörök az évek alatt egyre nagyobb gyakorlati ismeretre és tapasztalatra tettek szert az illegális pszichoaktív szerek felderítése területén.

A szállítási módszereket tekintve megállapíthatjuk, hogy ekkoriban a felderített kábítószercsempészek jellemzően testükön, illetve ruházatukba rejtve csempészték a tiltott anyagokat. Az 1993-ban regisztrált 32 kábítószer-felderítés elkövetőinek a fele próbált meg így bejuttatni illegális pszichoaktív szert Magyarország területére. ${ }^{26} \mathrm{Az}$ akkori év egyik legjelentősebb felderítésére Lőkösházán került sor, amikor a helyi vámhivatal munkatársai, az „Ovidius” nemzetközi gyorsvonat ellenőrzése során két amerikai turistánál mintegy 2,3 kilogramm heroint találtak. ${ }^{27}$

Az 1990-es évek végére - a heroin és kokain mellett - az amfetamin típusú kábítószerek tömeges megjelenése tovább színezte a magyarországi drogfogyasztó szubkultúrát. „Kialakult egy ifjúsági réteg, amelynél a hétvégi szórakozás elképzelhetetlen diszkó látogatás és amfetaminfogyasztás nélkül. A magyar bünözök reagálva a megnövekedett fogyasztói igényre egyre nagyobb tételekben csempészik be országunkba az amfetamin származékokat és az elosztás, a fogyasztókhoz történö eljuttatás egyre szervezettebben történik."28

Az amfetamin-típusú stimulánsok ${ }^{29}$ (ATS) megjelenése és használata, az eddig említett anyagokhoz hasonlóan sem a rendszerváltás időszakának hozadéka. Az amfetamint először 1887-ben írták le, azonban farmakológiai jelentőségére csupán 1927-ben figyeltek fel. ${ }^{30}$ 1932-ben a Benzedrin nevü gyógyszer hatóanyagként hozták forgalomba Németországban. Magyarországon ezt követően került törzskönyvezésre az amfetamin foszfát sója, Aktedron néven. ${ }^{31}$ Később, a szocialista időszakban meglehetősen sok amfetamint, vagy annak farmakológiai és kémiai tulajdonságaihoz rendkívül hasonló hatóanyagot tartalmazó gyógyszer került a magyar patikák polcaira. Ilyen volt az Aktedron mellett például a Gracidin, Centedrin vagy a Sydnocarb is. Ez utóbbiról, 1977-ben úgy számolt be a sajtó, mint a magyar-szovjet tudományos és müszaki együttmüködés kiváló eredményeként megszületett, a szellemi működést és éberséget serkentő termék. ${ }^{32}$

1979-től a látványosan terjedő stimuláns használat miatt, a Gracidin, a Centedrin és a Sydnocarb kiadását szigorították. ${ }^{33}$ Annak érdekében, hogy valamilyen szinten ellenőrizhetővé váljon a gyógyszerek forgalma, illetve beazonosíthatóak legyenek az esetlegesen visszaélő fogyasztók, az orvosi rendelvényekre rá kellett vezetni a gyógyszert kiváltók személyazonosító igazolványának a számát.

Az 1980-as évek közepére, egy rendőr hadnaggyal készített korabeli riport sorait olvasva, amolyan sajátságos magyar szocialista drogtér látványa bontakozik ki előttünk: „Menjen végig a forgalmasabb utakon és különös jeleket talál a házfalakon: nemcsak azt, hogy éljen az AC/DC együttes. Talál nagy A betüt karikában, ez a Aktedron. A nagy C karikában, a Centedrin, a G a Gracidin, a P a Parkáné, a CODNO a CodeinNoxyron koktél. Narcho - Anarcho hirdeti a Népköztársaság útján valaki. '34

A stimuláns hatású, vényköteles gyógyászati termékek kiadásának szigorításával a 1990-es évek - úgynevezett „diszkó-korszak” - fiataljainak igényeit tehát az alvilág drogüzérei igyekeztek kiszolgálni. Ezek a stimuláló szerek, a kokainhoz viszonyítva már akkor is jóval elérhetőbbnek számítottak. Egy gramm amfetamin ára 1993 és 1998 között megközelítőleg 1 000-3 000 forint között alakult, míg egy darab ún. ecstasy tablettát 800-2 000 forintért vásárolhatott a droghasználó. ${ }^{35}$ 
Az új szintetikus stimulánsok magyarországi elterjedésében 1995-ben jött létre áttörés. Azt megelőzően ugyanis a vámellenőrzések során egyáltalán nem derítettek fel ilyen anyagot. ${ }^{36} \mathrm{~A}$ rendszerváltást követő évtized második felében, a marihuána mellett az amfetamin típusú stimulánsok váltak a legkedveltebb anyagokká a magyar szerhasználók körében. 1998-ban a lefoglalt ecstasy tabletták száma csaknem elérte a 12000 darabot. ${ }^{37}$ 1996-ban feltünően sok levélpostai küldeményben is megtalálták az illegális serkentőket. ${ }^{38}$ A postán kívül a repülőtér, valamint az osztrák vámhatáron tartóztatták fel a legtöbb amfetamin típusú stimulánst. ${ }^{39} \mathrm{~A}$ heroinhoz hasonlóan, az amfetamin típusú kábítószerek térnyerését is jól fejezi ki az egészségügyi intézményekben nyilvántartott hazai fogyasztók számának dinamikus emelkedése. (II. sz. melléklet)

A Vám- és Pénzügyőrség törekvései a hazai amfetamin-piac bővülésének megakadályozására, a hatékony felderítések ellenére is csupán részsikerként voltak elkönyvelhetőek. A rendszerváltást követő időszakban ugyanis amfetamin típusú stimulánsok terjesztésében, a csempész csatornák mellett jelentős szerepet játszottak a hazai elóállítók is. Az 1990-es évek első felében számos külföldiek által müködtetett illegális laboratórium került felderítésre. ${ }^{40}$

A hazánkba telepedett nyugat-európai bünözöi körök felismerték, hogy az amfetamin-származékok elöállításához szükséges kiinduló anyagok gyártására, beszerzésére hazánkban szinte korlátlan lehetőségük van. Magyarország ugyanis a közép-kelet-európai régió más államaihoz viszonyítva már akkori is viszonylag fejlett vegyiparral és gyógyszergyártó iparral rendelkezett, amelyek jelentös mennyiségủ alapanyagot voltak képesek elöállítani, s ez elé a hiányos jogi szabályozás sem gördített akadályokat.

1992-ben a Borsodchem Rt. üzemében holland megrendelésre - állítólagos állatgyógyászati kísérletekhez - mintegy 300000 adagnak megfelelő MDE [3,4-(metilén-dioxi)-N-etil-amfetamin] típusú amfetaminszármazékot gyártottak a hazai joghézagok miatt gyakorlatilag legálisan. ${ }^{41}$ A Magyar Közlönyben ugyanis a midazolam nevü nyugtató, görcsoldó hatóanyag képletét - hibásan - MDE-nek rövidítették, s erre hivatkozva kaphatta meg a Borsodchem Rt. a gyártási engedélyt az amfetamin típusú stimuláns elóállitására. ${ }^{42}$

A fenti példa és az ahhoz hasonló esetek felkeltették a hatóságok figyelmét is. A kábítószerek és pszichotróp anyagok előállítása során felhasznált prekurzorokkal („elő-anyagok”) történő rendszeres visszaélések világossá tették, hogy azok ellenőrzése szintén kiemelt figyelmet kíván a vámhatóság részéröl.

A korszak kábítószer élvezőinek másik slágerterméke a marihuána, már korábban is jól ismert volt a hatóságok előtt. A szocialista korszak fiataljainak egy része, a hazánkban is megtalálható úgynevezett északi csoportba tartozó vadkender (Cannabis sativa ssp. sativa alfaj) leveleiből készített cigarettát. ${ }^{43}$ Hiszen ez az alfaj korlátozott THC ( $\Delta$ 9-tetrahidrokannabinol) tartalma miatt legálisan termeszthető. ${ }^{44}$ Ugyanakkor, mivel az indiai kender sem igényel túlzottan speciális körülményeket, voltak akik annak otthoni termesztésére vállalkoztak. Már az 1970-es években is több személlyel szemben indult eljárás marihuána előállítása miatt. Az egyik elkövető a becsempészett kendermagokból kinevelt növények leveleit feldolgozva 200 darab marihuánás cigarettát állított elő, melyek darabját 10 forintért értékesítette. ${ }^{45}$

$\mathrm{Az}$ 1990-es évek legelejére a marihuána fogyasztása mindennapos jelenséggé vált. ${ }^{46} \mathrm{Az}$ olcsó 500 - 1500 forintos $^{47}$ - beszerzési ár, illetve a könnyü hozzáférhetőség biztosította a marihuána térnyerését a fogyasztók között.

A növekvő keresleti igényt a Vám- és Pénzügyőrség felderítési mutatói is jól szemléltetik. Míg 1994ben csupán két esetben találtak marihuánát a pénzügyőrök, 1995-ben már három, 1996-ban öt, 1997-ben 46, 1998-ban pedig 56 alkalommal került lefoglalásra ilyen kábítószer. ${ }^{48}$

\section{A Vám- és Pénzügyőrség megelőző tevékenysége kábítószerek terjedésének területén}

A kábítószerek terjesztőivel szembeni küzdelemben már az elején világossá vált, hogy a Vám- és Pénzügyőrség nemzetközi segítség és együttmüködés nélkül nem lesz képes hatékony megelőző munkára. „,A nemzetközi szervezett bünözés ellen csak nemzetközi szervezett bünüldözéssel lehet fellépni eredményesen." fogalmazott BENCZE József, a Vám- és Pénzügyőrség Országos Parancsnokságának (VPOP) rendészeti föigazgatója 1999-ben. ${ }^{49}$

Megállapítható, hogy a rendszerváltást követően, kábítószer-csempészet mértékének jelentős növekedése nem állt arányban a magyar vámhatóság felkészültségével és tapasztalati tőkéjével. A nyugati társhatóságokhoz képest - a csempész módszerek, a felderítési technikák ismerete tekintetében - érezhető lemaradással küzdött a Vám- és Pénzügyőrség. Az 1980-as évek végén aztán megkezdődött a kapcsolatfelvétel és az együttmüködés a nyugati vámhatóságokkal. A magyar pénzügyőrök így lehetőséget kaptak arra, hogy a nyugati országok tapasztalt vámosaitól sajátíthassák el a kábítószerek csempészetével kapcsolatos elméletiés gyakorlati ismereteket, fogásokat. A tudatos felderítési módszerek fejlesztésében jelentős szerepet játszottak az Amerikai Egyesült Államok Kábítószer-ellenes Hivatalának (DEA) munkatársai, míg a bünügyi információk tekintetében a nyugat-európai államoktól kapott segítséget a hazai vámigazgatás. 
1977-től a Vám- és Pénzügyőrség egyre több országgal kötött kétoldalú vámigazgatási, bünmegelőzési kölcsönös segítségnyújtási megállapodást. 1977 és 1999 között összesen 19 országgal volt ilyen jellegủ megegyezése a magyar vámhatóságnak. ${ }^{50}$

A nemzetközi együttmüködést erősítendő, 1990. V. 8. és 1990. V. 10. között megrendezésre került Tihanyban a kábítószer-csempészet tapasztalatait feltáró és megosztó internacionális kábítószer-felderítési konferencia. „, A tihanyi konferencián - amelyen a Balkán-félszigettöl Nyugat-Európáig valamennyi érintett ország kábitószer-felderitő szervei képviseltették magukat - megtárgyalták a tranzitcsempészet problémáit, elemezték az ismertté vált elkövetési módszereket, a csempészettel gyanúsitható bünszövetségekre vonatkozó adatokat, és javaslatokat tettek a leleplezésükre irányuló összehangolt intézkedésekre., ${ }^{, 1}$

A kábítószer-üldözéssel kapcsolatos többlet feladatok koncepcionális és szervezeti változást követelt meg a Vám- és Pénzügyőrség vezetésétől. 1992-ben bevezetésre került az úgynevezett vám- és pénzügyőrségi drogstratégia. Az új koncepció legfőbb célkitüzése között szerepelt, hogy az addigi véletlenszerü felderítések elöre kidolgozott kritériumokra épülő, az elméleti és a gyakorlati tapasztalatokat ötvöző tudatos felderítésekké váljanak.

1992. IV. 1-jén megalakították a Különleges Ügyek Osztályát (1993. X. 1-től Főosztály), s azon belül pedig a Kábítószer-felderítési Csoportot (1993 októberétől Osztály). Ezt követően e szervezeti egység volt felelős a Vám- és Pénzügyörség kábítószer-felderítési tevékenységének koordinálásáért, összehangolásáért, valamint a befolyó információk feldolgozásáért és elemzéséért.

A pénzügyőrök sikerét, illetve az akkori kormányzat beléjük vetett bizalmát jól szemlélteti, hogy a szervezet 1992-es átalakítását követően, a következő évben már 73 millió forintos többletforrást biztosított a központi költségvetés a Vám- és Pénzügyőrség kábítószer-felderítő tevékenységére. ${ }^{52}$

A további sikerek érdekében, 1996. XI. 1-jén felállításra került a Központi Járőrszolgálat Parancsnoksága. A fővárosi székhelyü szervezeti egység 52 fő pénzügyőrrel kezdte meg müködését. A járőrszolgálat létrehozásának célja egy olyan három pontos ellenőrzési rendszer kialakítása volt, amely nem csupán az ország területére belépő, vagy az azt elhagyó forgalom ellenőrzését tette lehetővé, hanem - a mobil-felderítő csoportok révén - a belterületen is biztosította az ellenőrző, felderítő munkát.

A Központi Járörszolgálat Parancsnoksága, illetve a határvámhivatalok irányítása alatt összesen 28 kutató-csoport igyekezett felvenni a küzdelmet a kábítószercsempészekkel szemben. ${ }^{53}$

Napjaink technikai felszereltségéhez képest a kor pénzügyőrei valamivel egyszerübb eszközállománynyal voltak kénytelenek beérni. Habár az áru átvizsgálására szolgáló röntgen készülékröl legfeljebb más nemzetek gyakorlatából lehetett hallani, már akkor is detektorok, üregvizsgáló endoszkópok, infravörös lámpák segítették a felderítő munkát. ${ }^{54} \mathrm{~A}$ felszerelések beszerzéséhez szükséges erőforrások biztosításában jelentős segítséget nyújtottak más nemzetek kormányai, vámigazgatóságai, valamint az Egyesült Nemzetek Szervezete.

Az egyre szervezettebben müködö bünözői csoportok, valamint az esetlegesen felfegyverzett elkövetők elleni hatékony fellépés céljából, 1998-ban a Központi Járőrszolgálat Parancsnokságán belül megalakították a „Merkúr” bevetési egységet. A speciális képzettséggel, felszereléssel rendelkező csoport alkalmas volt többek között a kábítószer-bünözéssel érintett személyek elfogására, illetve a lefoglalt, jelentős vagyoni értéket képviselö kábítószer szállítmányok védelmére, kísérésére.

Szintén fontos szerep hárult a pénzügyőrök által alkalmazott szolgálati keresőkutyákra is. A Vám- és Pénzügyőrség 1973-tól kezdte meg a szolgálati kutyák használatát az ellenőrzések során. A kutyák és vezetőik képzését kezdetben a Rendőrség végezte, majd 1999-ben e feladat ellátását a Vám- és Pénzügyőri Iskola vette át. ${ }^{55} \mathrm{Az}$ ezredfordulót követően, 2001-től a szolgálati kutyák képzése már a Központi Járőrszolgálat Parancsnokságán folytatódott.

Idővel, a kábítószer-bünözéssel szembeni hatékonyabb fellépés érdekében a szervezeti átalakítás mellett, a jogszabályi környezet módosítása iránt is igény mutatkozott. A pénzügyőrök által felderített kábítószerbüncselekmények nyomozása ugyanis az 1990-es években kizárólagosan a Rendőrség hatáskörébe tartozott. Ugyanakkor többször felmerült problémaként, miszerint a felderítés és az elsődleges nyomozási cselekmények elvégzése között eltelt idő, jelentős érdeksérelmet okoz a későbbi büntetőeljárás eredményessége tekintetében. Az évtized végére egyre gyakrabban került napirendre a Vám- és Pénzügyőrség nyomozati hatáskör bővítésének gondolata. Az 1998. V. 28-án, „Vámosok a kábítószer ellen” címmel megrendezett nemzetközi konferencián a Vám- és Pénzügyőrség vezetői felhívták a figyelmet arra, miszerint az Európai Unió által elfogadott ajánlás is azt szorgalmazza, hogy a kábítószer-felderítés területén a rendőr- és vámhatóság azonos nyomozati jogkörrel lássa el tevékenységét. ${ }^{56} \mathrm{~A}$ folyamatos törekvések ellenére végül csupán 2003-ban, az új büntetőeljárási törvény hatályba lépésével került sor a Vám- és Pénzügyőrség hatáskörének bővítésére. 
A bünüldöző tevékenységén túl, a Vám- és Pénzügyőrség igyekezett közremüködni a keresletcsökkentést célzó akciókban is. Az 1992-es vám- és pénzügyőri drogstratégia a bűnözők által müködtetett kábítószerterjesztő csatornák lezárása mellett, célként határozta meg a pszichoaktív szerek iránti kereslet mérséklését is. Még ebben az évben, a VPOP a fiatalok kábítószer-fogyasztásának megelőzése érdekében felvilágosító kampányt indított Budapest 65 tanintézményében. ${ }^{57}$

1998-ban a hatóságok, az illegálisan előállított heroinnak mintegy 17\%, míg a kokainnak 40\%-át foglalták le a drogüzérektől szerte a világban. ${ }^{58}$

Ezek a számok is világosan kifejezik, hogy a hatóságok minden igyekezete ellenére, nem képesek önmagukban útját állni a kábítószerek terjedésének. A csempészek, üzérek épp úgy érdekeltek a fejlődésben, új módszerek és eszközök kidolgozásában, alkalmazásában, akárcsak az őket leleplezni kívánó állami szervezetek. A kábítószerek csempészete és az azok felderítése körül kialakult versenyben azonban mindig is a bünelkövetők diktálták a tempót. A hatóságok, legyenek bármennyire is proaktivitásra törekvők, a felderítések alkalmával elsősorban a már megszerzett tapasztalatokból merítik ismereteiket. Ebből szükségszerủen következik, hogy az első lépést minden alkalommal az elkövetők teszik meg. Ez a tény pedig rendkívüli előnyt biztosít az üzérek számra. A jelenség bemutatására újságcikkek is születtek. „, A tengerészek bevallása szerint minden teher-vagy átlagosnál nagyobb utasszállitó hajón több mint 30000 rejtekhely van, ahová el lehet dugni kábitószert vagy akármilyen csempészárut. A vámörök, a csempészés elleni szakértök ismernek talán 29 ezret, de nem ismerhetik a többit. ${ }^{, 59}$

A kábítószerek és más pszichoaktív anyagok okozta társadalmi nehézségek megoldásában ugyanakkor nem elég csupán a a rendvédelmi testületek munkájára támaszkodni. A pszichoaktív anyagok elóállításából, csempészetéből vagy felhasználásából származó következmények összessége kollektív közösségi tevékenység eredményei. Azaz e következmények mértéke, minősége, illetve megjelenési formái a társadalom különböző alrendszerei által befolyásoltak. A politika, az egészségügy, a közigazgatás, az oktatás, a társadalom történelmi, kulturális hagyományai, biológiai- és pszichés sajátosságai egyaránt befolyásolják azt, hogy az adott közösségben a különböző pszichoaktív szerek - elöállítása, terjesztése vagy használata - milyen változásokat idéznek elö, s hogy ezeket miként kezelik. A kollektivitásból eredően, e következmények hatékony befolyásolásában tehát egyetlen közösségi alrendszer önmagában tehetetlen.

Összességében megállapítható, hogy a kábitószerfogyasztás elleni tevékenységi körben a Vám- és Pénzügyőrség elsődleges funkciója a kínálat csökkentése úgy vélem, hogy ez a megállapítás mind a mai napig megállja a helyét. Így tehát az 1990-es évek Vám- és Pénzügyörségének egy rendkívül bonyolult társadalmi jelenség kezelésében kellett közremüködnie. Ennek ellenére kijelenthetjük, hogy e nagy múltú szervezet akkor is megállta a helyét. A Vám- és Pénzügyőrség sikerét elsősorban nem a magyarországi drogtérben előidézett változások jelzik hanem az, hogy társadalmi rendeltetésének megfelelően ekkor is minden szervezeti átalakításával, a fejlődés iránti igényével arra törekedett, hogy a jogszabályokat megtartsa és azokat másokkal is megtartassa.

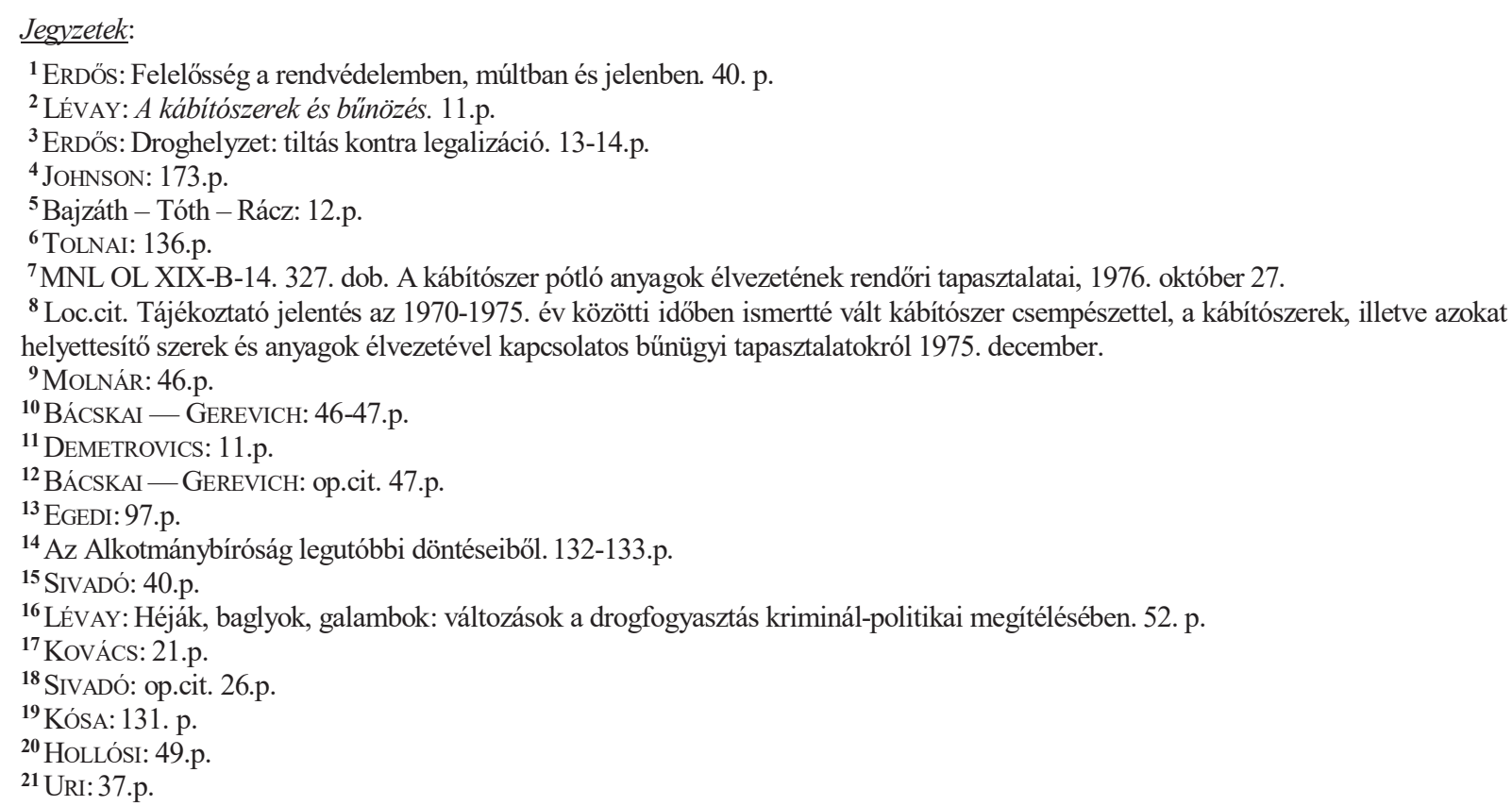


${ }^{22}$ BEBESI: 123.p.

${ }^{23}$ KósA: op.cit.

${ }^{24}$ BALÁS: 58.p.

${ }^{25}$ BARÁTH - MÉSZÁROS: 44.p.

${ }^{26}$ Loc.cit. 46.p.

${ }^{27}$ Heroin a vonaton.

${ }^{28}$ KósA: op.cit.

${ }^{29}$ Amfetamin típusú stimulánsnak tekinthető: ad. 1. az amfetamin és izomerjei (pl.: dexamfetamin); ad. 2. amfetaminszármazékok (az amfetamin alapmolekulára „épített” vegyületek; ad. 3. amfetaminhoz hasonló vagy azzal megegyező hatású vegyületek (pl.: metilfenidát).

${ }^{30}$ UJVÁRY: Az amfetamin-típusú drogok kultúrtörténete, kémiája, farmakológiája és toxikológiája. 646.p.

${ }^{31}$ BAYER: 248.p.

32 Új gyógyszer magyar-szovjet együttmüködés alapján.

${ }^{33}$ BAJZÁTH - TÓTH - RÁCZ: op.cit. 33.p.

${ }^{34}$ Szombat este harapunk.

${ }^{35}$ TOPOLÁNSZKY - RITTER

${ }^{36}$ BALÁS: op.cit.

${ }^{37}$ UjvÁRY: Az amfetamin-típusú drogok kultúrtörténete, kémiája, farmakológiája és toxikológiája. op.cit.

${ }^{38}$ TORKOS: 13.p.

${ }^{39}$ BALÁs: op.cit. 55.p.

${ }^{40}$ KósA: op.cit. 133.p.

${ }^{41}$ UJVÁRY: Az amfetamin-típusú drogok kultúrtörténete, kémiája, farmakológiája és toxikológiája. op.cit. 651.p.

${ }^{42}$ Idem: Ádám és Éva: A kémiai dzsungel tiltott gyümölcsei. 75. p.

${ }^{43}$ HUBER - KisSZÉKELYI — NÉMETH: 160.p.

${ }^{44}$ BENÉCSNÉ : 8.p.

${ }^{45}$ MNL OL XIX-B-14 ORFK op.cit. 327. dob. - Tájékoztató jelentés az 1970-1975. év közötti időben ismertté vált kábítószer csempészettel, a kábítószerek, illetve azokat helyettesítő szerek és anyagok élvezetével kapcsolatos bünügyi tapasztalatokról, 1975. dec.

${ }^{46}$ BÁCSKAI - GEREVICH: 47.p.

${ }^{47}$ TOPOLÁNSZKY - RITTER: op.cit.

${ }^{48}$ BENCZE: 947.p.

${ }^{49}$ BALÁs: op.cit. 19.p.

${ }^{50}$ BENCZE: op.cit. 948.p.

${ }^{51}$ Lezárják a „Balkán-útvonalat”. Nemzetközi kábítószer-felderítési konferencia Tihanyban.

${ }^{52}$ SZABÓ Margit: 6. p.

${ }^{53}$ BALÁs: op.cit. 16.p.

${ }^{54}$ BARÁTH - MÉSZÁROS: op.cit. 31-32.p.

${ }^{55}$ PÁlinKÁs: 94. p.

${ }^{56}$ KovÁCsICS: op.cit. 139-140.p.

${ }^{57}$ Drogellenes akció: 1.p.

${ }^{58}$ BAYER: op.cit. 21.p.

${ }^{59}$ SZABÓ Endre: 4.p.

Forrás-és irodalomjegyzék (a jegyzetekben alkalmazott röviditések oldása):

\section{MONOGRÁFIÁK, KISMONOGRÁFIÁK ÉS HASONLÓ JELLEGÛ KÖTETEK}

BAJZÁTH - TÓTH - RÁCZ

(5.;33.;)

BAYER

(31.;58.;)

Demetrovics

(11.;)

HUBER - KISSZÉKELYI — NÉ- - METH

(43.;)

JOHNSON

(4.;)

LÉVAY: A kábítószerek és bünözés.

(2.;)
BAJZÁTH Sándor - TóTH Eszter Zsófia - RÁcz József: Repülök a gyógyszerrel - A kábitószerezés története a szocialista Magyarországon. Budapest, 2014, L'Harmattan Kiadó. 226 p. HU-ISBN 9789632368115.

BAYER IsTVÁN: Drogok és emberek - múlt, jelen, jövő. Budapest, 2005, Focus Kiadó. 512 p. HU-ISBN 963946841 X.

DeMETROVICH Zsolt: Drogkultúra, drogfüggőség, társkapcsolatok. Budapest, 1997, Magyar Tudományos Akadémia Politikai Tudományok Intézete Etnoregionális Kutatóközpont. 80 p. HU-ISBN 9638300833.

/MTA PTI Etnoregionális Kutatóközpont Munkafüzetek, 27./ HU-ISSN 1416-8391.

/Ultrakissebbségek Magyarországon, 1./ HU-ISSN 1417-5622.

HuBER Béla - KisszéKELYI Ödön - NÉMETH Zsolt: A bódulat csapdájában. Budapest, 1989, Tankönyvkiadó. 212 p. HU-ISBN 9631820815.

JOHNSON Diane Louise: Claudius Aelianus' Varia historia and the tradition of miscellany. [Claudius Aelianus' Varia historia és a vegyes irományok hagyományai.] Oxford, 1997, N.G. Wilson - Harvard University Press. 520 p. GB-ISBN 978067499535 2. /Loeb Classical Library, 486./ GB-ISSN -

LÉVAY Miklós: A kábitószerek és bünözés. Budapest, 1992, Közgazdasági és Jogi Kiadó. 269 p. HU-ISBN 9632225279. 


\section{TOLNAI}

(6;)

TOPOLÁNSZKY - RITTER (35.;47.;)

\section{TANULMÁNYOK}

BÁCSKAI - GEREVICH (10.;12.;46.;)

BEBESI

(22.;)

HollósI

(20.;)

KÓsA

(19.;23.;28.;40.;)

UJVÁRY: Az amfetamin-típusú drogok kultúrtörténete, kémiája, farmakológiája és toxikológiája.

(30.;37.;41.;)

URI

(21.;)

\section{CIKKEK}

Az Alkotmánybíróság legutóbbi döntéseiből.

(14.;)

BENCZE

(48.;50.;)

Drogellenes akció.

ERDŐs: Felelősség a rendvédelemben, múltban és jelenben.

(1.;)

ERDŐs: Droghelyzet: tiltás kontra legalizáció.

(3.;)

Heroin a vonaton.

(27.;)

Lezárják a „Balkán-útvonalat”. Nemzetközi kábítószer-felderítési konferencia Tihanyban. (51.;)

LÉVAY: Héják, baglyok, galambok: változások a drogfogyasztás kriminálpolitikai megítélésében. (16.;)

PÁLINKÁS (55.;)

\section{SzABÓ Endre}

(59.;)

SzABÓ Margit

(52.;)

Szombat este harapunk.

(34.;)

Új gyógyszer magyar-szovjet együttműködés alapján.

(32.;)
TOLnAI Kálmán: Kábulat. Budapest, 1986, Népszava Lap- és Könyvkiadó. 368 p. HU-ISBN 9633223881.

TOPOLÁNSZKY Ákos-RITTER Ildikó: Jelentés a magyarországi kábitószer helyzetről. Budapest, 1999, Ifjúsági- és Sportminisztérium. 183 p. HU-ISBN — /ISMertető, 1./ HUISSN 1785-3721.

BÁCSKAI Erika — GEREVICH József: Adalékok a magyarországi droghelyzet tisztázásához. Esély, V.évf. (1993) 6.sz. 46-51.p. HU-ISSN 0865-0810.

BeBESI Zoltán: A kokalevéltől a kokainig. Győri Tanulmányok. Tudományos Szemle, XXXIX.évf. (2001) 25.sz. (Hedonizmus) 119-128.p. HU-ISSN 0209-4215.

Hollósi GYÖRGY: Elveszett évtized a kábítószer elleni harcban. Belügyi Szemle, XLV.évf. (1997) 11.sz. 49-58.p. HU-ISSN 1218-8956.

KóSA LÁSzLÓ: Kábítószer helyzet Magyarországon a harmadik évezred küszöbén. Győri Tanulmányok. Tudományos Szemle, XXXIX.évf. (2001) 25.sz. (Hedonizmus) 129-142.p. HU-ISSN 0209-4215.

UJVÁRY ISTVÁN: Az amfetamin-típusú drogok kultúrtörténete, kémiája, farmakológiája és toxikológiája. Psychiatria Hungarica, XV.évf. (2000) 6.sz. 641-687.p. HUISSN 0237-7896.

URI LÁSZLÓ: Kábítószer-ültetvények Koszovóban. Belügyi Szemle, LX.évf. (2012) 2.sz. 35-45.p. HU-ISSN 1789-4689.

Az Alkotmánybíróság legutóbbi döntéseiböl. (Szerkesztőségi közlemény) In Fundamentum, IX.évf. (2005) 1.sz. 132-136.p. HU-ISSN 1417-2844.

BENCZE József: A feketegazdaság elleni fellépés eredményei. Statisztikai Szemle, LXXVII.évf. (1999) 12.sz. 932-951.p. HU-ISSN 0039-0690.

Drogellenes akció. Nógrád Megyei Hirlap, III.évf. (1992) 299.sz. 1.p. HU-ISSN 0865-9095.

ERDŐs Ákos: Felelősség a rendvédelemben, múltban és jelenben. Magyar Közigazgatás, LXI.évf. (2011) 2.sz. 118-121.p. HU-ISSN 0865-736X.

ERDŐs Ákos: Droghelyzet: tiltás kontra legalizáció. Magyar Rendészet, XV.évf., (2015) 3.sz. 11-26.p. HU-ISSN 1416-3845.

Heroin a vonaton. (Szerkesztőségi közlemény). Új Dunántúli Napló, IV.évf. (1993) 237.sz. 3.p. HU-ISSN 0865-9133.

Lezárják a „Balkán-útvonalat”. Nemzetközi kábítószer-felderítési konferencia Tihanyban. (Szerkesztőségi közlemény). Ujj Dunántúli Napló, I.évf. (1990) 37.sz. 2.p. HU-ISSN 0865-9133.

LÉVAY Miklós: Héják, baglyok, galambok: változások a drog-fogyasztás kriminálpolitikai megítélésében. Fundamentum, V.évf. (2001) 1.sz. 49-57.p. HU-ISSN $1417-$ 2844.

PÁLINKÁs András: A szolgálati kutyák alkalmazásának feladatköre és a feladatok alkalmazásának nehézségei. 94-105.p. In SzABÓ Andrea — ZsÁMBOKINÉ Ficskovszki Ágnes: Az adó- és vámszolgálatok aktuális kihívásai. Konferencia és tanulmánykötet. Budapest, 2016, Nemzeti Közszolgálati Egyetem Rendészettudományi Karának Vámés Pénzügyőr Tanszéke - Magyar Rendészettudományi Társaság Vám- és Pénzügyőr Szakosztálya. 215 p. HU-ISBN 9789631249330.

SzABÓ Endre: Mákony - Mámor - Gyilkosság. Szolnok Megyei Néplap, XXIII.évf. (1972) 103.sz. 3-4.p. HU-ISSN 0133-0756.

SzABÓ Margit: Akik leeresztették a sorompót a drogcsempészek előtt. Új Dunántúli Napló, I.évf. (1990) 14.sz. 6.p. HU-ISSN 0865-9133.

Szombat este harapunk. Magyar Ifjúság, XXIX.évf. (1985) 46.sz. 16.p. HU-ISSN 0460-5551.

Új gyógyszer magyar-szovjet együttmüködés alapján. Békés Megyei Népújság, XXXII.évf. (1977) 21.sz. 1.p. HU-ISSN 0133-0055. 
UJvÁRY: Ádám és Éva: A kémiai dzsungel tiltott gyümölcsei.

(42.;)
UJvÁRY István: Ádám és Éva: A kémiai dzsungel tiltott gyümölcsei. Élet és Tudomány, XLVIII.évf. (1993) 3.sz. 74-75.p. HU-ISSN 0013-6077.

\section{LEVÉL- IRAT- ÉS DOKUMENTUMTÁRI GYÜJTEMÉNYEK}

MNL OL XIX-B-14.

(7.;8.;45.;)

\section{REGISZTRÁL KÉZIRATOK}

BALÁS

(24.;36.;39.;49.;53.;)

BARÁTH - MÉSZÁROS

(25.;26.;54.;)

BENÉCSNÉ

(44.;)

EGEDI

(13.;)

MOLNÁR

(9.;)

SIVADÓ

(15.;18.;)

TORKOS

(38.;)

\section{EMLÉKKÖNYVEK}

\section{KovÁCSICS}

(17.;56.;)

\section{Mellékletek jegyzéke:}

I.sz. melléklet

Kokain felderítések a Vám- és Pénzügyőrségnél 1990-1995.

II.sz. melléklet

Magyarországon nyilvántartott kábítószer-fogyasztók 1995-1999.

Kokain felderítések a Vám- és Pénzügyörségnél 1990-1995.

\begin{tabular}{|l|l||l|l||l|l||l|l||l|l||l|l|}
\hline \multicolumn{2}{|l||}{1990} & \multicolumn{2}{|l||}{1991} & \multicolumn{2}{|l||}{1992} & \multicolumn{2}{|l|}{1994} & \multicolumn{2}{l|}{1995} \\
\hline \hline Eset & $\begin{array}{l}\text { Súly } \\
(\mathrm{gr})\end{array}$ & Eset & $\begin{array}{l}\text { Súly } \\
\text { (gr) }\end{array}$ & Eset & $\begin{array}{l}\text { Súly } \\
(\mathrm{gr})\end{array}$ & Eset & $\begin{array}{l}\text { Súly } \\
\text { (gr) }\end{array}$ & Eset & $\begin{array}{l}\text { Súly } \\
\text { (gr) }\end{array}$ & Eset & $\begin{array}{l}\text { Súly } \\
\text { (gr) }\end{array}$ \\
\hline 0 & 0 & 4 & 8660 & 6 & 8041 & 3 & 2418 & 6 & 24984 & 8 & 18480 \\
\hline
\end{tabular}

Forrás ! Bebesi Zoltán: A kokalevéltől a kokainig. 125.p. Győri Tanulmányok. Tudományos Szemle, XXXIX.évf. (2001) 25.sz. (Hedonizmus) 119-128.p. HU-ISSN 0209-4215.

\section{Magyarországon nyilvántartott kábítószer-fogyasztók 1995-1999.}

\begin{tabular}{|l|l|l|}
\hline Év & Nyilvántartott heroin-fogyasztók száma & $\begin{array}{l}\text { Nyilvántartott } \\
\text { amfetamin-fogyasztók száma }\end{array}$ \\
\hline 1995 & 286 & 108 \\
\hline 1996 & 502 & 301 \\
\hline 1997 & 1689 & 929 \\
\hline 1998 & 1576 & 1367 \\
\hline 1999 & 1846 & 1334 \\
\hline
\end{tabular}

Forrás ! Nemzeti Stratégia a kábitószer-probléma visszaszoritására. Budapest, 2000, Ifjúsági- és Sportminisztérium, Budapest. 89 p. HU-ISBN 9630037033. 